\title{
Integrating Strategic Considerations and Value Co-creation in Project Management
}

\author{
Yuval Cohen ${ }^{1, *}$, Shai Rozenes ${ }^{1}$, Roni Horowitz ${ }^{2}$ \\ ${ }^{1}$ Industrial Engineering and Management Department, Afeka Academic College of Engineering, Israel \\ ${ }^{2}$ Industrial Engineering and Management Department, Azrieli Academic College of Engineering, Israel
}

Copyright $\bigcirc 2017$ by authors, all rights reserved. Authors agree that this article remains permanently open access under the terms of the Creative Commons Attribution License 4.0 International License

\begin{abstract}
While traditional project management advocates sticking to a baseline plan (composed of budget, schedule and specifications) this paper suggests a new planning approach that includes re-evaluation and optimizes the project's value while allowing strategic changes in the project scope, budget and schedule. The proposed optimization allows taking into account not only the project, but also the long term impact of changes on cash-flows, product reliability, firm reputation, and customer satisfaction. Such changes are not part of the traditional project management approach of sticking to the baseline and eliminating a scope creep. Such a new approach enables dealing with many important changes that occur during long term projects. This is particularly important in projects with large amount of uncertainty where new knowledge is revealed or discovered during the project lifespan, and significant events occur that impact the project or its deliverables. The paper analyses the factors that make this approach desirable and the type of projects where this approach would be especially attractive.
\end{abstract}

Keywords Project Management, Strategic Management, Strategic Decision

\section{Introduction}

Traditionally, the project management literature has been mainly occupied with the efficient and timely execution of specifications and producing a deliverable artifact or a system [1]. As a result, project management processes and tools are focused on enhancing on time, on budget and according to specifications performance [2,3]. Training has been cited as one approach for enhancing project performance [4]. This approach is tactical, and its sole focus is on efficient delivery of specified outputs. But it clearly neglects the strategic importance of the project realization. The strategic importance of the project is typically obtained only after the project is done. For example, even if project outputs have been delivered efficiently the project can still be ineffective to the funding organization. Examples are the Sydney cross-city tunnel [5] and the Los Angeles Metro [6]. Another well-known example is the famous Sydney opera building which was far from being on time and on budget, but is a great success for the long run. Recently, a wider view on the management of projects has emerged, which also discusses the delivery of strategic goals by projects $[7,8]$. Project benefit management research emphasizes the strategic roles of projects in organizations. (e.g., [9]) and defines the benefit management process (e.g., [10]). Consequently, benefit management is becoming an important research area. Project benefits are "the flows of value that arise from a project" [11]. A project owner is accountable to the project funder/founder for the realization of these target benefits [11].

In this paper we lay a conceptual framework for the interface between a project and its strategic considerations.

\section{Integrating Strategic Considerations in Project Management}

In this section we describe the proposed model. The section describes the effect of changes on cash flow diagrams. A cash flow diagram shows the incoming and outgoing sums of money along the timeline. Often the project is described on the cash flow diagram as an initial investment, and the monthly or annual income in the future years. Figure 1 illustrates this scenario.

\subsection{Time Related Effects}

There are only few ways that time changes may play strategic role. The first of these is the project delay. This means that the project finishes with a delay and the project benefits could not be realized during the delay period [12]. The obvious effect on the cash flow is the elimination of any revenue (and any project benefit) during the delay [13]. Figure 2 illustrates the net effect of simple delay imposed on 
a project.

A delay may be a result of external events or forces, but may also be a strategic decision related to the quality of the project deliverables. In that case, the delay can contribute to the quality of the project. This could be translated directly to better reputation and could also increase the revenues after the project is completed. For example, a delay related to enhancing the external appearance of a restaurant may increase (by certain \%) the number of customers and therefore the revenue. The delay may also be related to enhancing the reliability of the project deliverable which results in extension of its profitable life. These two effects are depicted in Figure 3.

In reality the decisions are more subtle and are taken in the level of detailed activity network. This level also involves uncertainties related to times and cash flows. This level would be described and analyzed with examples in the full paper.

\subsection{Budget Related Effects}

The project budget is usually displayed on a cash-flow diagram as one amount investment. Just as the time dimension of a project can affect the long-term strategic time span, budget has very similar impact:

- Increasing budget could contribute to the quality of the project deliverable

- Increasing budget may contribute to the reliability of the project deliverable

- Increasing budget may shorten the completion time or counter a delay imposed by external constraints.

Figure 4 depicts the effects of budget changes.

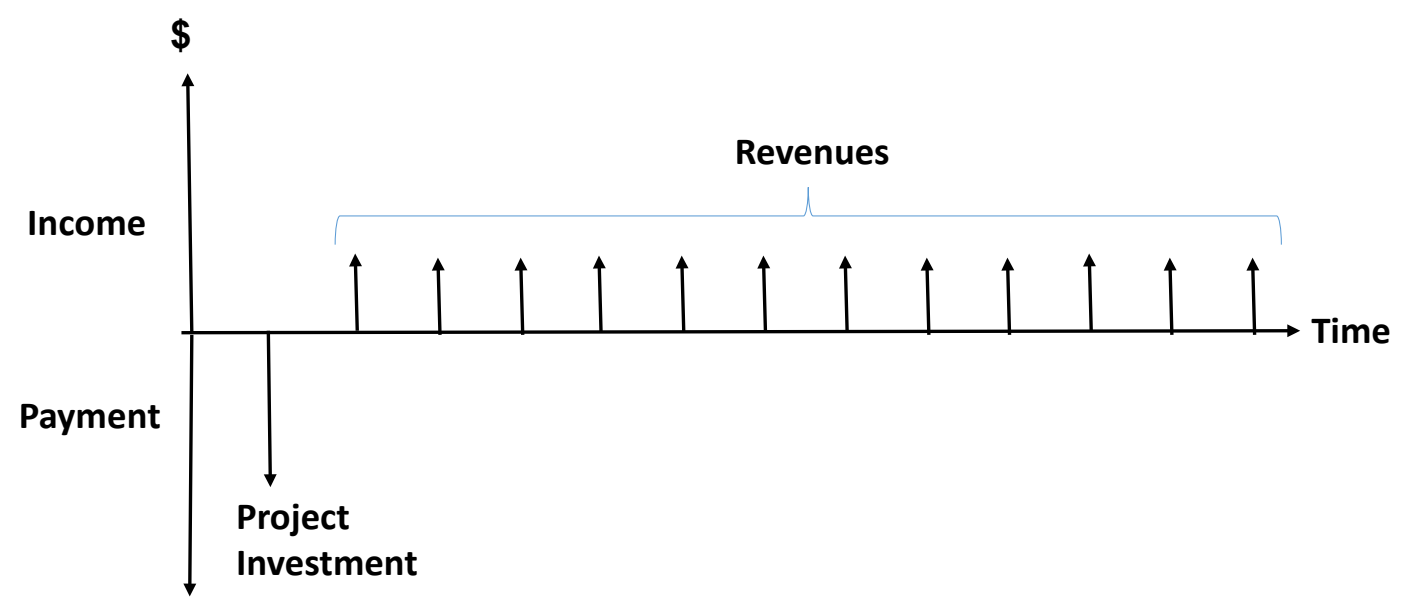

Figure 1. The cash flow related to a specific project

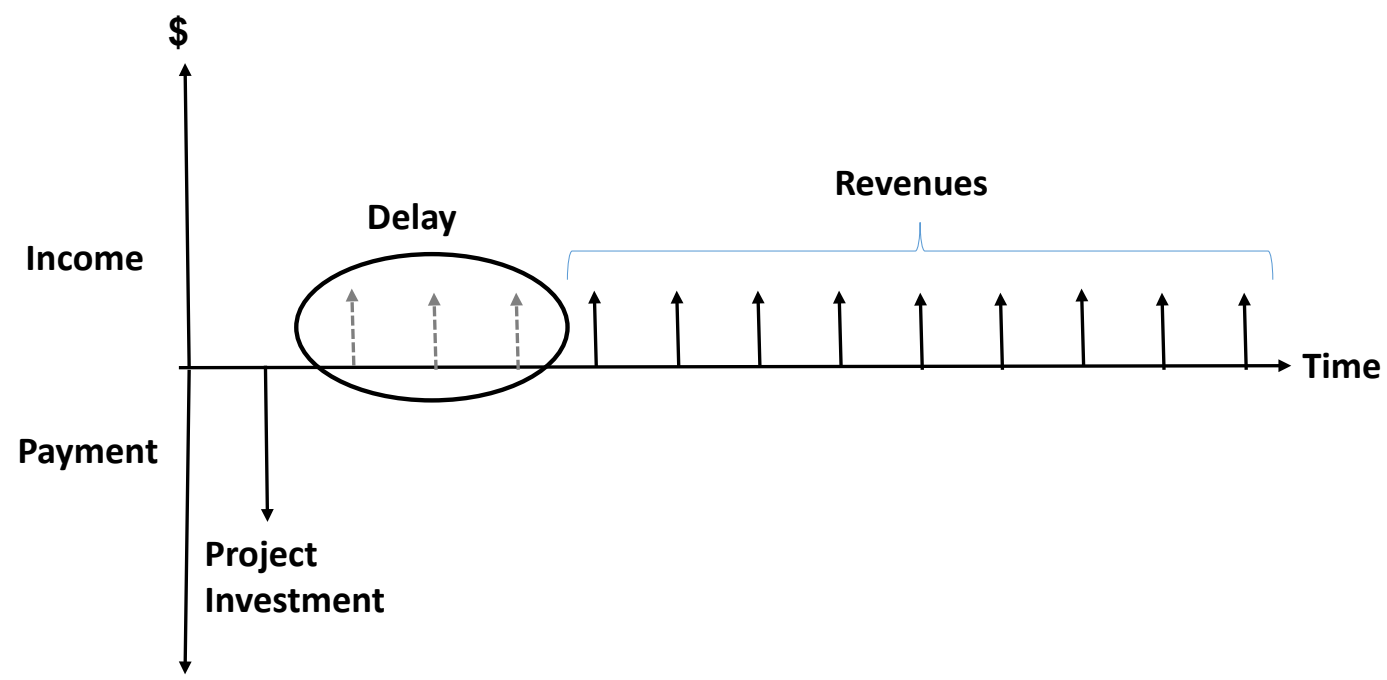

Figure 2. The effect of simple delay on the cash flow related to a specific project 


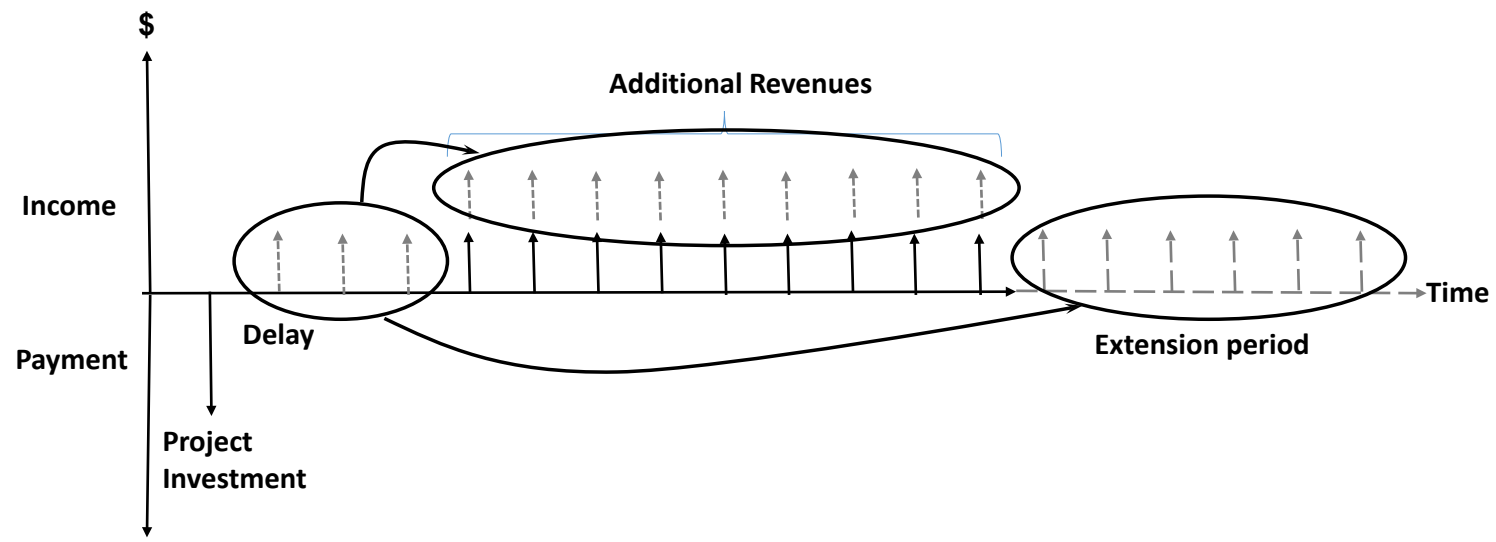

Figure 3. The effect of a delay on the revenues size and period in a cash flow related to a specific project

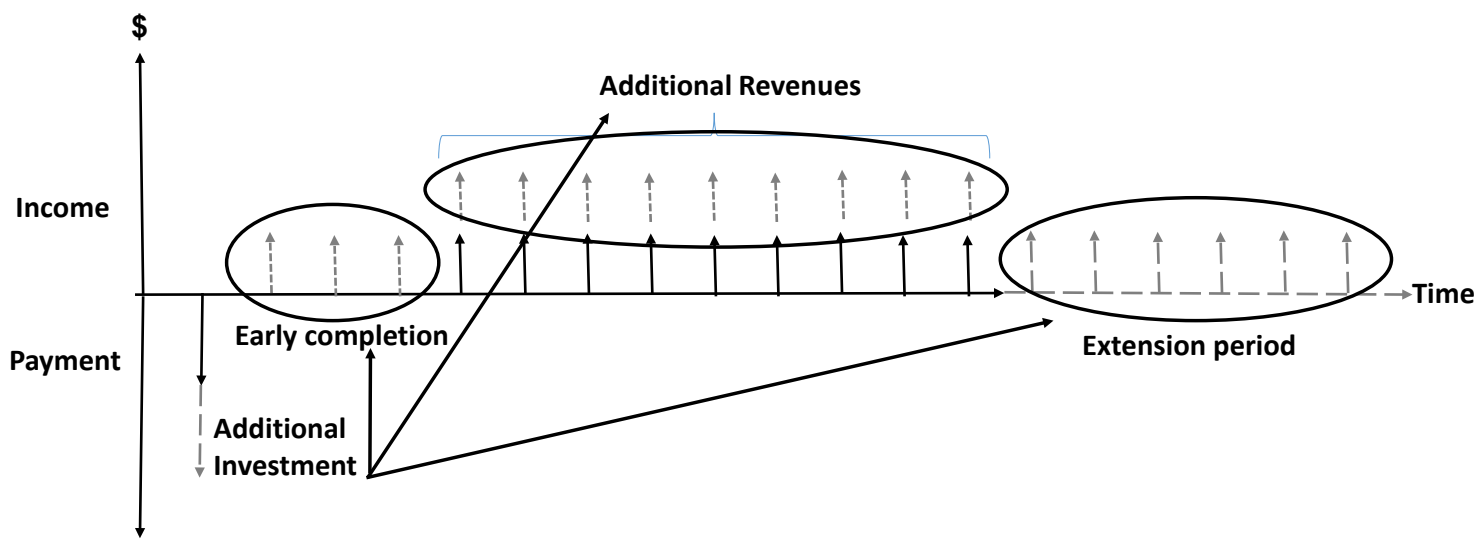

Figure 4. The possible effects of additional budget on the project's related cash-flows

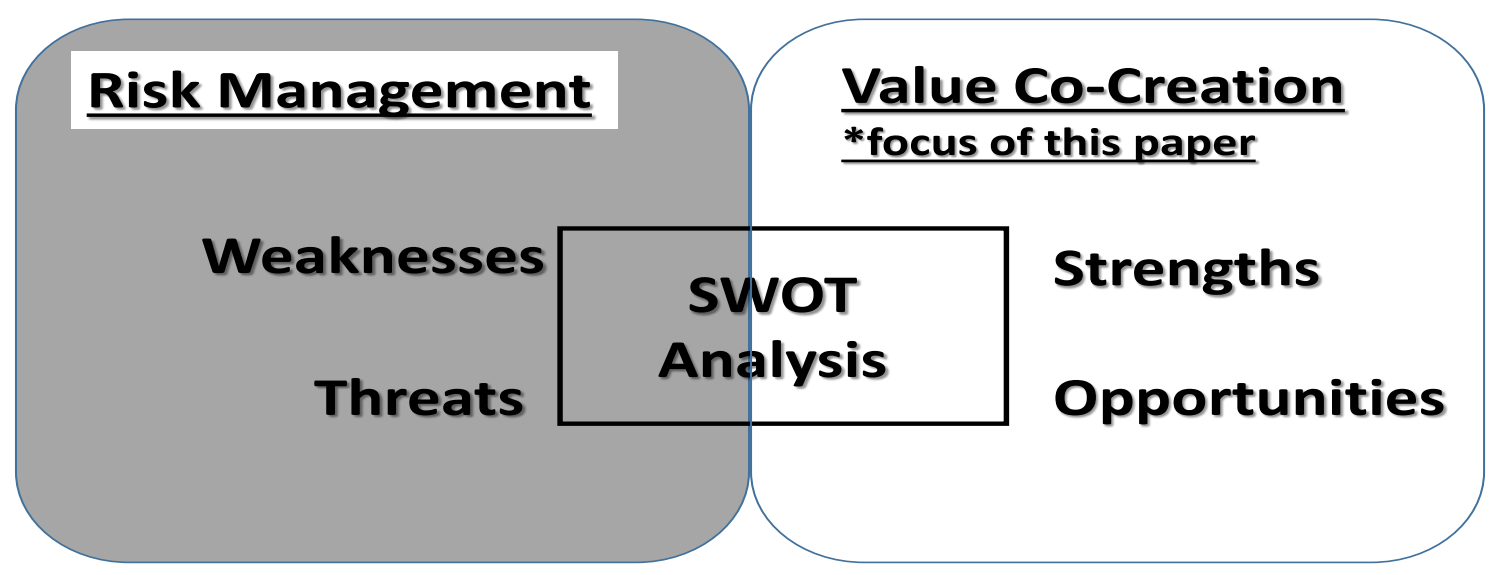

Figure 5. The focus of value co-creation in the SWOT analysis 
In reality the decisions are more subtle and are taken in the level of detailed activity network. This level also involves uncertainties related to costs and cash flows. One classic example is the famous Sydney Opera House. This project took 15 years (from 1958 to 1973) and 14 times the original budget (from A\$7 million to A $\$ 102$ million) to build, yet, today it stands proudly as an engineering masterpiece and the symbol of Sydney [14].

\section{Integrating Value Co-creation in Project Management}

Value Co-creation is a new way of managing the outsourcing of project and the relationship between the project team and the project customer. In this approach, the outsourcing organization (the customer) and the project contractor build mutual partnership for maximizing the project performance and its opportunities.

In such a framework, the contractor is not left alone to be responsible for on time on budget and on spec performance [14], but is rather accompanied by managers from the customer organization in a partnership style team. The major characteristics of such a partnership are:

1. Frequent periodic mutual meetings (contractor and customer organization teams) for update and discussions related to risk management and opportunities.

2. The request for proposal leads for finding a partner and leaves large flexibility related to the actual execution (time, budget, spec.).

3. The budget for the project must include at least four components:
a. Reserve component (for opportunities)
b. Second reserve component (for risks)
c. Partnership incentive component
d. Baseline execution component $(60 \%$ to $70 \%$ of total budget)

Consulting projects are classical projects where value co-creation could be naturally achieved. Some of the mechanisms leading the contractor and customer teams are related to the framework of formal and informal relationships between customer and contractors. Therefore, we suggest that both the customer and the contractor should choose team members that would work together to monitor the project. One barrier to realize the benefit could be the budget. Therefore, we propose to divide the budget into three parts: (1) fixed based on estimates, (2) safety buffer budget for justified over runs, (3) budget for motivating collaboration between customer and contractor.

\section{Value Co-creation in the Integrated Project}

There are many more benefits of running the integrated project (instead of the pure contractual approach) in addition to the time perspective. The first advantage of managing the project together is the ability to look at the project from a strategic perspective and if necessary change the project boundaries (scope, budget, and timetable) [15-16]. This leads to the recognition that the customer and contractor are partners to the same project, and value co-creation is the outcome of this partnership. The creation of value is the core purpose and central process of economic exchange. Traditional models of value creation focus on the firm's output and price [17]. Grönroos and Voima (2013) [18] defined value co- creation as follows: "customers' creation of value-in-use; co-creation is a function of interaction. Both the firm's and the customer's actions can be categorized by spheres (provider, joint, customer), and their interactions are either direct or indirect, leading to different forms of value creation and co-creation".

This concept of value co-creation must be understood through the concept of Service Dominant Logic (SDL). SDL (Lusch \& Vargo, 2006; Vargo \& Lusch, 2004, 2008a, 2008b, 2016 [19-23]) presents a framework that pivots around the customer experience and revolves around co-creation of value. SDL endorses the concept that all human economic activities are elements of service. In this regard describing the activity level of a relevant population would be directly related to customers and providers' activities.

Traditional PM practices focus on the risk management and threats of a project. Risk management is defined as one of the main subjects in the PMBOK, and so is the stakeholder management. The proposed approach has the benefit of adding strength and opportunities. Realizing these opportunities require making changes in project's scope and planning processes. This is justified since it contributes strategic value to the project.

Establishing the mutual governance framework requires integrating the customer and the contractor management teams. This is required to perform the integrated project instead of two separate projects. Each team should always include the following experts: technical, financial, timeline, scope, and marketing (represents the customer experience).

The integration of the contractor team and customer team generates synergy. As Aristotle (384 - 322 BC) said "The whole is greater than the sum of its parts". As an example, the customer has the strategic view of the impact of project changes (in the advertising campaign project these would be related to content and market segment), and with the professional advice of the contractor can improve the project execution (e.g., the professional design of the campaign message, and the selection of distribution channels). Furthermore, integrated teams of the contractor and the customer can reach a mutual understanding of the needs and the technical requirements in a synergistic way which is quite similar to the synergy in concurrent engineering (Chhabra \& Emami, 2014 [24]).

It follows from the discussion above that in order to take advantage of strategic opportunities; the customer must be involved in the project management process. In such a case, the customer remains in active strategic control over the 
outsourcing activity. In such a framework the outsourcing only relieves the customer from the execution details, but allows the customer to focus on the governance. This is in contrast to the traditional approach that outsourcing relieves the customer from the entire subject.

\section{Conclusions}

Traditional project management is formed around building a sound baseline plan and sticking to its execution. This mode of thinking emphasizes the threats to the project and foster risk management. Project failures during the last decades have highlighted weaknesses in the traditional approaches to project management and in particular their failure to cope with strategic events. Dynamics approaches provide a utilitarian tool for a more systematic management of these strategic issues. The conflicts of opinion between their supporters stress the different perspectives underlying the two approaches. The comparison of the approaches is focused on the "view" of the task management process. Although, in the end, they both assume a system perspective, identifying a cycle of planning, implementation and control, the level of detail in which they consider the project system is different. Traditional models support the project manager in the detailed operational problems within the process, while dynamics approach provides more strategic insights and understanding about the effectiveness of different managerial policies.

This paper presents a novel dynamic approach that focuses on the long term perspective of the project benefits and incomes, rather than on the classic iron triangle of scope time and budget. In this paper we point at the opportunities side. These opportunities may either come from the strategic understanding of the project team, or the partnership between the outsourcing customer company and the project contractor. Understanding the project objectives in a strategic way will contribute to the entire project organization.

\section{REFERENCES}

[1] Rozenes S, Vitner G, Spraggett S. (2006) Project control: Literature review. Proj Manag J.; 37(4):5-15.

[2] Keren, B., Cohen, Y. (2012), “Optimizing Project Performance: The Triangular Trade-off Optimization Approach", International Journal of Engineering Management and Economics (IJEME), Vol. 3, No. 1, pp. 152-170.

[3] Rozenes, S., Vitner G., Spraggett S. (2006), "Project Control: Literature Review", Project Management Journal, vol. 37, No. 4, pp.5-14.

[4] Rozenes, S., Vitner G., (2009),'The training methodology of a Project Management Office (PMO)", Industrial and
Commercial Training., Vol. 41, No. 1.

[5] Zwikael, O., Smyrk, J. R. (2011), "Project Management for the Creation of Organisational Value". Springer-Verlag, London.

[6] Shenhar, A. J., Dvir, D. (2007), Reinventing Project Management: The Diamond Approach to Successful Growth and Innovation. Harvard Business School Press, Boston, MA.

[7] Gareis, R., Stummer, M. (2008), Processes and Projects, Manz, Vienna.

[8] Morris, P.W.G., Jamieson, A. (2008), “ Implementing strategy through programmes of projects", In Turner, J.R. (Ed.), Gower Handbook of Project Management, 4th ed. Aldershott, Gower.

[9] Kolltveit, B. J., Karlsen, J. T., Grønhaug, K. (2007)," Perspectives on project management". International Journal of Project Management, Vol. 25, pp. 3-9.

[10] Breese, R. (2012), "Benefit realisation management: panacea or false dawn?" International Journal of Project Management, Vol. 30, pp. 341-351.

[11] Zwikael,O., Smyrk, J. R. (2012), “A general framework for gauging the performance of initiatives to enhance organizational value", British Journal of Management, Vol. 23, pp. S6-S22.

[12] Cohen, Y., Sadeh, A., Zwikael, O. (2012), "Finding the Shortest Non-Delay Schedule for a Resource-Constrained Project", International Journal of Operations Research and Information Systems (IJORIS), Vol. 3, No. 4, pp. 41-58.

[13] Cohen, Y., Zwikael, O. (2010), “A New Technique for Estimating the Distribution of a Stochastic Project Makespan", International Journal of Information Technology Project Management (IJITPM), Vol. 1, No. 3, pp. 14-27.

[14] Lim, C. S., Mohamed, M. Z. (1999). "Criteria of project success: an exploratory re-examination", International Journal of Project Management Vol. 17, No. 4, pp. 243-248.

[15] Rozenes, S. (2012). "The Impact of Project Management Methodologies on Project Performance ", J. Wang (ed), "Perspectives and Techniques for Improving Information Technology Project Management", ch 2, pp. 14-23, IGI Global, 2012.

[16] Pinto, J. K. (2015). "Project Management: Achieving Competitive Advantage" (4th ed.), Prentice Hall, USA

[17] Vargo, S. L., Maglio, P.P., Akaka, M. A. (2008). On value and value co-creation: A service systems and service logic perspective, European Management Journal, Vol. 26, pp. $145-152$.

[18] Grönroos C., Voima P. (2013). Critical service logic: making sense of value creation and co-creation, Journal of the Academy of Marketing Science, Vol. 41, No. 2, 133-150.

[19] Lusch, R. F., \& Vargo, S. L. (2006). Service-dominant logic: reactions, reflections and refinements. Marketing Theory, Vol. 6, No. 3, pp. 281-288.

[20] Vargo, S. L., \& Lusch, R. F. (2004). Evolving to a new dominant logic for marketing. Journal of Marketing, Vol. 68, No. 1, pp. 1-17.

[21] Vargo, S. L., \& Lusch, R. F. (2008a). Service-dominant logic: 
continuing the evolution. Journal of the Academy of Marketing Science, Vol. 36, No. 1, pp. 1-10.

[22] Vargo, S. L., \& Lusch, R. F. (2008b). Why "service"? Journal of the Academy of Marketing Science, Vol. 36, No. 1, pp. $25-38$.
[23] Vargo, S. L., \& Lusch, R. F. (2016). Institutions and axioms: an extension and update of service-dominant logic. Journal of the Academy of Marketing Science, Vol. 44, No. 1, pp. 5-23.

[24] Chhabra, R., \& Emami, M. R. (2014). "A holistic approach to concurrent engineering and its application to robotics". Concurrent Engineering, Vol. 22, No. 1, pp. 48-61. 